\title{
Effect of fermentation temperature on the properties of exopolysaccharides and the acid gelation behavior for milk fermented by Streptococcus thermophilus strains DGCC7785 and St-143
}

\author{
Som N. Khanal* and John A. Luceyt ${ }^{1}$ \\ *Department of Food Science, and \\ †Center for Dairy Research, University of Wisconsin-Madison, 1605 Linden Drive, Madison 53706
}

\begin{abstract}
We investigated the effect of fermenting milk with 2 strains (DGCC7785 and St-143) of Streptococcus thermophilus, which are known to produce different types of exopolysaccharide (EPS) structures. The yields and physical properties of these ropy EPS were monitored during the fermentation of milk at different temperatures. We wanted to understand how these types of EPS properties affected yogurt gelation. Reconstituted skim milk was fermented at 33,39 , or $45^{\circ} \mathrm{C}$ until $\mathrm{pH}$ values reached 5.2, 4.9, 4.7, and 4.5. Molar mass of ropy EPS samples was determined using size exclusion chromatography coupled with multiangle laser light scattering. Rheological properties of fermented milk gels were analyzed using small-strain dynamic oscillatory measurements. In both strains, concentrations of ropy EPS increased during fermentation and at all temperatures. Fermentation times, by both strains, were shortest at $45^{\circ} \mathrm{C}$ and longest at $33^{\circ} \mathrm{C}$. For both strains, molar mass of ropy EPS ranged from 2 to $4 \times$ $10^{6} \mathrm{~g} / \mathrm{mol}$ during fermentation. A major proteinaceous contaminant that was co-isolated with the ropy EPS fraction by our isolation method was identified as a milk-derived phosphoglycoprotein PP3. Increase in fermentation temperature from 33 to $45^{\circ} \mathrm{C}$ significantly decreased the storage modulus values (from 170 to 41 $\mathrm{Pa}$ ) for milk gelled by strain DGCC7785, whereas the gels made with St-143 had very low storage modulus values (11-17 $\mathrm{Pa}$ ) regardless of fermentation temperatures. For both strains, the values of maximum loss tangent in the milk gels increased with fermentation temperature; the maximum loss tangent occurred at higher $\mathrm{pH}$ values when milk was fermented by strain DGCC7785. The specific type of EPS produced ap-
\end{abstract}

Received May 21, 2017.

Accepted January 8, 2018.

${ }^{1}$ Corresponding author: jlucey@cdr.wisc.edu peared to be responsible for the differences in yogurt texture rather than the concentration or molar mass of the EPS.

Key words: exopolysaccharides, fermented milk, Streptococcus thermophilus

\section{INTRODUCTION}

Many lactic acid bacteria (LAB), including Streptococcus thermophilus strains, are known to produce highmolecular-weight exopolysaccharides (EPS), mainly heteropolysaccharides, during the fermentation of milk. Lactic acid bacteria produce 2 forms of EPS, namely slimy or ropy EPS and capsular EPS. The EPS that is liberated into the growth medium is believed to cause stringy or slimy appearance, and this type is called ropy EPS (i.e., unattached to the cells). Production of EPS by LAB depends on several parameters, such as levels of nutrients and environmental factors (e.g., $\mathrm{pH}$, temperature, and oxygen; Gassem et al., 1997; GamarNourani et al., 1998; Torino et al., 2001a,b; Vaningelgem et al., 2004a). Bacteria are believed to produce ropy EPS for protection against different stresses, such as environmental stress, desiccation, and bacteriophage attack (Cerning, 1990; Hassan, 2008; De Vuyst et al., 2001). Bacterial cells also feel stress due to deprivation of adequate nutrients, and presence of sublethal amounts of physical and chemical factors may hinder their normal growth, thereby triggering EPS biosynthesis (Cerning, 1990). Even though LAB are often believed to synthesize EPS in response to certain kinds of stresses, EPS is mainly produced during their active growth phase (De Vuyst et al., 1998; Degeest et al., 2001).

Rheological properties of acid milk gel produced by bacterial fermentation, or by glucono- $\delta$-lactone, depends on rate of acidification as well as the fermentation temperature. An increase in fermentation temperature results in a decrease in the strength of acid gels (Lucey et al., 1998; Lee and Lucey, 2003; Lee and Lucey, 2004). Exopolysaccharide-forming, and non- 
EPS forming, strains of $S$. thermophilus may produce acid milk gels with different rheological properties (Hassan, 2008). For example, most EPS-producing $S$. thermophilus strains enhanced the strength of milk gels compared with non-EPS strains, except for some specific strains, such as St-143, which we have reported to produce slightly weaker gels (Khanal and Lucey, 2017). The rheological properties of milk gels formed by different ropy EPS producing strains of $S$. thermophilus were highly strain-dependent, possibly due to differences in the quantity, type, and properties of their respective EPS (Pachekrepapol et al., 2017).

In most previous studies, the isolation of EPS was based on chemical precipitation of EPS from the fermentation medium (Tallon et al., 2003; Leroy and De Vuyst, 2016; Mende et al., 2016). We reported that some EPS isolated by chemical precipitation methods (along with lyophilization) may lose some of its solubility, which makes characterization of the physical properties difficult (Pachekrepapol et al., 2017). We hypothesized that altering the fermentation temperature would affect the quantities and possibly properties of the ropy EPS produced by $S$. thermophilus strains, as fermentation temperature affects growth rate as well as stress on LAB. Changes in the amount or properties of EPS could affect the rheological properties of milk gels during the fermentation process. An UF-based method of EPS isolation was used in the current study to separate EPS, in a soluble form, and determine the amount of ropy EPS. We selected 2 strains, St-143 and DGCC7785, for this study because they are known to produce different types of EPS structures (Pachekrepapol et al., 2017) and we aimed to understand how these EPS would affect the rheological properties of milk gels.

\section{MATERIALS AND METHODS}

\section{Reconstitution of Milk}

Low-heat nonfat dry milk powder (Dairy America, Fresno, CA) with a whey protein nitrogen index of 7.56 $\mathrm{mg}$ of undenatured whey protein per gram of powder was reconstituted by dispersing $12 \mathrm{~g}$ of powder in 100 $\mathrm{g}$ of distilled water (DW) and stirring at room temperature for $3 \mathrm{~h}$. Reconstituted milk was then heated at $85^{\circ} \mathrm{C}$ for 30 min using a water bath, cooled to $\sim 5^{\circ} \mathrm{C}$, and stored in refrigerator for up to $24 \mathrm{~h}$ before use.

\section{Preparation of Cultures}

Two strains of Streptococcus thermophilus, namely St-143 (Chr. Hansen, Hørsholm, Denmark) and
DGCC7785 (Danisco, Madison, WI), were used in our study. Strains St-143 and DGCC7785 are known to produce ropy EPS when grown in milk (Pachekrepapol et al., 2017). At $40^{\circ} \mathrm{C}$, strains St- 143 and DGCC7785 were reported to produce 43 and up to $110 \mathrm{mg}$ of glucose equivalent (GE) of EPS per kilogram of milk, respectively (Pachekrepapol et al., 2017).

Approximately $2 \mathrm{~mL}$ of frozen culture (at $-80^{\circ} \mathrm{C}$ ) of each individual strain was inoculated into $500 \mathrm{~mL}$ of autoclaved (i.e., heated at $121^{\circ} \mathrm{C}$ for $15 \mathrm{~min}$ ) and cooled skim milk, which was incubated at $40^{\circ} \mathrm{C}$ until milk was gelled $(\mathrm{pH} \sim 5.0)$. The fermented milk was aseptically transferred into several 5 -mL sterile cryogenic vials (Fisher Scientific, Pittsburgh, PA) and stored frozen at $-80^{\circ} \mathrm{C}$ for use as a stock (mother) culture (Lee and Lucey, 2004). Fresh working culture was prepared before use by inoculating $1 \mathrm{~mL}$ of the stock culture into $80 \mathrm{~mL}$ of autoclaved and cooled milk and then incubated at $40^{\circ} \mathrm{C}$ for $\sim 4 \mathrm{~h}(\mathrm{pH} \sim 5.0$; Lee and Lucey, 2004).

\section{Fermentation of Milk and Monitoring of $\mathrm{pH}$}

To try to achieve similar acidification rates at $40^{\circ} \mathrm{C}$, reconstituted milks for strains St-143 and DGCC7785 were supplemented with 2 and $0.2 \%$ (wt/vol) BD Bacto peptone (Becton, Dickinson and Company, Franklin Lakes, NJ), respectively. Streptococcus thermophilus grows poorly in milk when grown without the other culture used for yogurt fermentation, Lactobacillus bulgaricus (this is strain-dependent; Tamime and Robinson, 1999). Reconstituted milk media (1.5 L) were heated at $85^{\circ} \mathrm{C}$ for 30 min in a water bath, cooled to the fermentation temperature, and inoculated with $2 \%$ ( vol/vol) of the freshly prepared working culture of each individual strain. For EPS production/isolation, exactly $1.35 \mathrm{~L}$ of inoculated milk was filled into $1,000-\mathrm{mL}$ and two 250-mL sterile Pyrex media bottles (Corning, Corning, NY; the 250-mL bottles were each about half filled) and tightly capped without leaving any visible head space to create approximate anaerobic condition (which could have a minor effect of growth rates). Milk samples were incubated at 33,39 , or $45^{\circ} \mathrm{C}$ in a Precision Low Temperature incubator (Thermo Fisher Scientific, Marietta, OH). Milk was fermented to $\mathrm{pH}$ values of 5.2 , $4.9,4.7$, and 4.5 before isolation of EPS. To monitor the changes in $\mathrm{pH}$ values during fermentation, 50 to $70 \mathrm{~mL}$ of this inoculated milk was poured in a $100-\mathrm{mL}$ glass vial and a $\mathrm{pH}$ probe connected to a computer controlled model PCM 700 Orion Sensor Link system (Orion Research Inc., Beverly, MA) was immersed into the milk. The exposed surface of the milk in the vials with the $\mathrm{pH}$ probe was covered with sterile mineral oil. 


\section{Rheological Properties of Milk During Fermentation}

Parallel rheological analyses and $\mathrm{pH}$ measurements were carried out on fermented milks (milks were splitsampled to enable rheological properties recorded during fermentation to be converted into $\mathrm{pH}$ values; Lee and Lucey, 2004). A Paar Physica rheometer (MCR 301, Anton Paar, Ashland, VA) was used to determine the rheological properties of milk gels during fermentation at the different temperatures by performing nondestructive, small-strain dynamic oscillatory measurements in a cup and bob geometry (CC27-SN23928) consisting of 2 coaxial cylinders with diameters of 26.7 and $28.9 \mathrm{~mm}$. Inoculated milk was aseptically transferred to the rheometer and the milk surface in the measuring geometry was covered with sterile mineral oil to avoid evaporation. An oscillatory frequency of 1 $\mathrm{Hz}$, with $0.5 \%$ strain, was applied to milk during the entire fermentation period. Values for storage modulus $\left(\mathbf{G}^{\prime}\right)$ and loss tangent ( $\left.\mathbf{L T}\right)$ were recorded every 5 min until the $\mathrm{pH}$ values of milk reached $\sim 4.5$. During fermentation, milk was considered to be gelled when the $\mathrm{G}^{\prime}$ values of the gel exceeded $1 \mathrm{~Pa}$ (Lucey et al., 1998). The $\mathrm{pH}$ time curves from the computerized $\mathrm{pH}-$ recording system was used to convert the time data measured by the rheometer into $\mathrm{pH}$ rheology profiles.

\section{Isolation and Quantification of Ropy EPS}

Ropy EPS from fermented milk were isolated using the tangential flow UF method described by $\mathrm{Li}$ et al. (2011) with some modifications. Fermented milk sample $(1.35 \mathrm{~L})$ was immediately heated at $85^{\circ} \mathrm{C}$ for $10 \mathrm{~min}$ to stop the fermentation and inactivate any EPS degradation enzymes present (Leroy and De Vuyst, 2016). It is possible that the heat treatment could have released some capsular EPS as well. The sample was then left undisturbed for 10 to 15 min while hot and the whey was collected by decantation. Most of the remaining whey in the curd was also recovered by centrifuging the curd at $500 \times g$ for 5 min at $25^{\circ} \mathrm{C}$ using an Avanti J-E centrifuge (Beckman Coulter, Brea, CA). We assumed that unattached (ropy) EPS was in the soluble phase. The objective of these methods was to try to retain as much as possible of the bacteria in the whey (we examined the whey and the curd fractions by light microscopy and most bacteria appeared to be in the whey fraction). Whey was then UF at $45^{\circ} \mathrm{C}$ through a $100-$ $\mathrm{kDa}$ Prep/Scale TFF spiral-would tangential flow UF membrane module (Millipore, Bedford, MA). Permeate was discarded [we checked the viscosity of the permeate and it was low, which we took as indication that (high-molecular-weight) EPS was retained in the UF retentate] and retentate was sufficiently diafiltered with DW to remove small sugars (as indicated by the absence or minimal carbohydrate content in the permeate as indicated by the phenol sulfuric acid analysis). After $\mathrm{UF}$, the retentate was collected, $\mathrm{pH}$ was adjusted to 4.6 by the addition of $0.1 \mathrm{~N} \mathrm{HCl}$, heated without stirring at $80^{\circ} \mathrm{C}$ for $5 \mathrm{~min}$, and then centrifuged at $10,000 \times g$ for $15 \mathrm{~min}$ at $25^{\circ} \mathrm{C}$. The supernatant was analyzed for the ropy EPS content.

The phenol sulfuric method (Dubois et al., 1956) was used for determination of the EPS content in the final EPS aliquot. Standard curve for the phenolic sulfuric acid method was obtained using various known concentrations of dextran (Sigma-Aldrich, St. Louis, MO; average molar mass of $2 \times 10^{6} \mathrm{~g} / \mathrm{mol}$ ), which is a similar molar mass to the EPS produced by most $S$. thermophilus strains (Pachekrepapol et al., 2017). The EPS content in the aliquots extracted from the samples obtained during fermentation were determined using the standard curve; DW was used as blank for ropy EPS determination.

\section{Determination of Molar Mass of Isolated EPS}

Molar mass was determined for the ropy EPS fraction. The supernatant containing ropy EPS was concentrated to one-fifth of its original volume using an Amicon stirred UF cell (Millipore) with a 10-kDa Millipore disc membrane. Size exclusion chromatography-multi angle laser light scattering (SEC-MALLS) was used to determine the molar mass of isolated, ropy EPS, as described by Wang and Lucey (2003) and Pachekrepapol et al. (2017). Waters e2695 HPLC separation module (Waters, Milford, MA) was connected to SEC Superose 12HR 10/300 and 6HR 10/300 columns (Amersham Pharmacia Biotech AB, Uppsala, Sweden) in series. Three detectors, namely a model 2998 photodiode array detector operating at $280 \mathrm{~nm}$ (Waters), a DAWN EOS MALLS photometer system (Wyatt Technology, Santa Barbara, CA) fitted with a helium neon-laser $(\lambda$ $=690 \mathrm{~nm}$ ) and a K-5 flow cell, and a model $2414 \mathrm{RI}$ detector (Waters), were all used in this system.

Insoluble impurities, and any dust, in the isolated EPS samples were removed by filtering the solutions through a $0.22-\mu \mathrm{m}$ syringe filter (Millipore); $100 \mu \mathrm{L}$ of filtrate was then injected into the SEC-MALLS system that was operated at $\sim 1,725 \mathrm{kPa}$ and a flow rate of $0.5 \mathrm{~mL} / \mathrm{min}$. The chromatograms were analyzed for the intensities of the refractive index (RI) and UV signals. The peaks with higher RI signals and correspondingly low (or no) UV signals at $280 \mathrm{~nm}$ were confirmed to be EPS peaks. Molar mass, polydispersity (PD), and radius of gyration $(\mathbf{R} \boldsymbol{g})$ of the EPS molecules were de- 
termined by the Astra software version 4.73.04 (Wyatt Technology) using the Debye fitting method (Wang and Lucey, 2003). A refractive index increment value of $0.14 \mathrm{~mL} / \mathrm{g}$ was used for polysaccharides (di Cagno et al., 2014). Monomeric BSA (molar mass of $66.4 \times$ $10^{3} \mathrm{~g} / \mathrm{mol}$; Sigma-Aldrich, St. Louis, MO) was used to calibrate the SEC-MALLS system.

\section{Identification of Contaminants in the SEC-MALLS Chromatogram of Isolated EPS}

In reviewing the major peaks obtained for the SECMALLS chromatogram of ropy EPS, the major peak that had high MALLS and RI signals, as well as low UV signal, was considered as the EPS fraction. Another fraction was observed, and this proteinaceous fraction (because of a high UV signal) exhibited high signals for all 3 detectors, MALLS, RI, and UV. The SEC-MALLS profiles were compared before and after hydrolysis by trypsin and chymotrypsin. Approximately $15 \mathrm{~mL}$ of the isolated EPS sample was adjusted to $\mathrm{pH} 9.0$ by addition of $0.05 \mathrm{M} \mathrm{NaOH}$ in some samples. To a portion of each sample, $1 \mathrm{~mL}$ of bovine trypsin and chymotrypsin (Sigma-Aldrich) enzyme cocktail (containing $1.5 \mathrm{mg} /$ $\mathrm{mL}$ of each enzyme) was added and incubated at $50^{\circ} \mathrm{C}$ for $5 \mathrm{~h}$ for the hydrolysis of any contaminating protein. Molar masses of EPS were determined before and after protein hydrolysis.

To identify the nature of this contaminant, during SEC-MALLS the sample corresponding to this proteinaceous peak was collected, dialyzed against 10

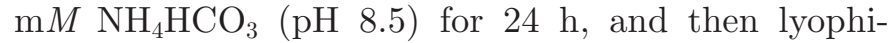
lized. Liquid chromatography-MS/MS was used for identification of this protein containing material in the Biotechnology Center (University of WisconsinMadison) according to the procedure described by Del Valle-Echevarria et al. (2015). The lyophilized sample was solubilized in $1 \mathrm{~mL}$ of water and proteins were extracted from $500 \mu \mathrm{L}$ with trichloroacetic acid/acetone precipitation $(10 \%, \mathrm{wt} / \mathrm{vol}$, trichloroacetic acid, $28 \%$, vol/vol, acetone, final concentration). Pellet was resolubilized and denatured in $15 \mu \mathrm{L}$ of $8 \mathrm{M}$ urea/50 $\mathrm{m} M \mathrm{NH}_{4} \mathrm{HCO}_{3}(\mathrm{pH} 8.5) / 1 \mathrm{~m} M$ Tris- $\mathrm{HCl}$ and subsequently diluted to $60 \mu \mathrm{L}$ followed by reduction with 2.5 $\mu \mathrm{L}$ of $25 \mathrm{~m} M$ dithiothreitol, $5 \mu \mathrm{L}$ methanol, and 37.5 $\mu \mathrm{L}$ of $25 \mathrm{mM} \mathrm{NH}_{4} \mathrm{HCO}_{3}$ (pH 8.5). The material was incubated at $52^{\circ} \mathrm{C}$ for $15 \mathrm{~min}$, cooled on ice to room temperature, then $3 \mu \mathrm{L}$ of $55 \mathrm{~m} M$ iodoacetic acid was added for alkylation in darkness for $15 \mathrm{~min}$. Reaction was quenched by adding $8 \mu \mathrm{L}$ of $25 \mathrm{~m} M$ dithiothreitol, before addition of $8 \mu \mathrm{L}$ of trypsin/LysC (Promega, Madison, WI) solution (100 ng/ $\mu \mathrm{L}$ of trypsin/LysC in $25 \mathrm{mM} \mathrm{NH}_{4} \mathrm{HCO}_{3}$ ), and $100 \mu \mathrm{L}$ final volume was made up by adding $25 \mathrm{mM} \mathrm{NH}_{4} \mathrm{HCO}_{3}(\mathrm{pH}$ 8.5). Protein hy- drolysis was conducted for $2 \mathrm{~h}$ at $42^{\circ} \mathrm{C}$, an additional 4 $\mu \mathrm{L}$ of trypsin/LysC solution was added and hydrolyzed further at $37^{\circ} \mathrm{C}$, and hydrolysis was finally terminated by acidification with $2.5 \%$ trifluoroacetic acid to $0.3 \%$ (wt/vol) final concentration.

The protein hydrolysate was purified using OMIX C18 SPE cartridges (Agilent, Palo Alto, CA), as per manufacturer's protocol (https://www.agilent.com/ cs/library/primers/Public/5990-9049EN-Omix-Sept11 -lo.pdf), and eluted in $20 \mu \mathrm{L}$ of $60 / 40 / 0.1 \%$ (vol/vol) acetonitrile $/ \mathrm{H}_{2} \mathrm{O}$ /trifluoroacetic acid buffer, dried to completion in the SPD1010 speed-vacuum concentrator (Thermo Fisher Scientific, Waltham, MA), and finally reconstituted in $45 \mu \mathrm{L}$ of $0.1 \%$ (wt/vol) formic acid. Peptides were analyzed by nanoLC-MS/MS as described by Del Valle-Echevarria et al. (2015). For the peptides eluted from the HPLC-column/electrospray source, MS scans were acquired in the Orbitrap with a resolution of 120,000 full width at half maximum, followed by MS2 fragmentation of the 20 most intense peptides detected in the MS1 scan from 300 to 2,000 $\mathrm{m} / z$, and redundancy was limited by dynamic exclusion.

Raw MS/MS data were converted to mgf file format using MSConvert (Kessner et al., 2008) to search against NCBInr Bos taurus AA sequence database (https:// www.ncbi.nlm.nih.gov/genome/82) with decoy reverse entries and a list of common contaminants (91,456 total entries). Uniprot Streptococcus thermophilus AA sequence database (18,718 total entries) was also searched using in-house Mascot search engine 2.2.07 (Matrix Science, Boston, MA) with variable methionine oxidation with asparagine and glutamine deamidation. Peptide mass tolerance was set at $15 \mathrm{mg} / \mathrm{L}$ and fragment mass at 0.6 Da. Protein annotations, significance of identification, and spectral-based quantification was done with help from Scaffold software (version 4.3.2, Proteome Software Inc., Portland, OR). Protein identifications were accepted if they could be established at greater than $80.0 \%$ probability within $1 \%$ false discovery rate and contained at least 2 identified peptides. Protein probabilities were assigned by the protein prophet algorithm.

\section{Statistical Analysis}

A $3 \times 4$ full factorial experiment was designed with 3 temperatures and $4 \mathrm{pH}$ values. Experiments were repeated twice with duplicates $(\mathrm{n}=4)$. Experiments for rheological properties of milk gels were repeated at least 3 times. Means were compared by ANOVA and Tukey-Kramer HSD using JMP Pro 11.0 (SAS Institute Inc., Cary, NC) software, with significance indicated by $P<0.05$. 


\section{RESULTS}

\section{Fermentation of Milk}

The $\mathrm{pH}$ values of milk during fermentation by $S$. thermophilus strains St-143 and DCCC7785 are shown in Figure 1. Although the 2 strains had a similar acidification rates at $45^{\circ} \mathrm{C}$ (not surprising, as we adjusted the peptone levels at $40^{\circ} \mathrm{C}$ to try to achieve similar rates), we noted differences in acidification profiles at the other fermentation temperatures. Samples fermented by strain DGCC7785 took much longer (between 150 to $200 \mathrm{~min}$ ) to reach $\mathrm{pH} 4.5$ when fermented at 33 or $39^{\circ} \mathrm{C}$ (compared with strain St-143).

\section{Yield of Ropy EPS During Fermentation}

The yields of ropy EPS produced by $S$. thermophilus strains St-143 and DGCC7785 during the fermentation of milk at various temperatures are shown in Table 1. When milk was fermented at 33 or $45^{\circ} \mathrm{C}$ by St-143, the yield of ropy EPS at pH 5.2 was $\sim 97 \mathrm{mg} / \mathrm{L}$, which reached $\sim 120 \mathrm{mg} / \mathrm{L}$ when $\mathrm{pH}$ of milk reached 4.5 (Table 1). At $39^{\circ} \mathrm{C}$, yield of ropy EPS significantly increased from 124 ( $\mathrm{pH} 5.2$ ) to $179 \mathrm{mg} / \mathrm{L}$ ( $\mathrm{pH} 4.5$ ) during fermentation (Table 1). The yield of ropy EPS was significantly $(P<0.05)$ affected by fermentation temperature and sampling $\mathrm{pH}$. The yield of ropy EPS produced by DGCC7785 during fermentation of milk at 33 or $39^{\circ} \mathrm{C}$ were mostly similar, and yields increased significantly during fermentation (Table 1). Compared with 33 or $39^{\circ} \mathrm{C}$, lower yields of ropy EPS were observed during the fermentation period at $45^{\circ} \mathrm{C}$ (Table 1 ).

\section{Molar Mass of EPS During Fermentation}

Ropy EPS was isolated using the UF method that kept the isolated EPS in solution. In the SEC-MALLS chromatograms, the peaks with high MALLS and RI signals, as well as no or very weak corresponding UV signals, were considered for determination of molar mass of ropy EPS. The ropy EPS peak in most of the samples eluted between 26 and 32 min of retention
A
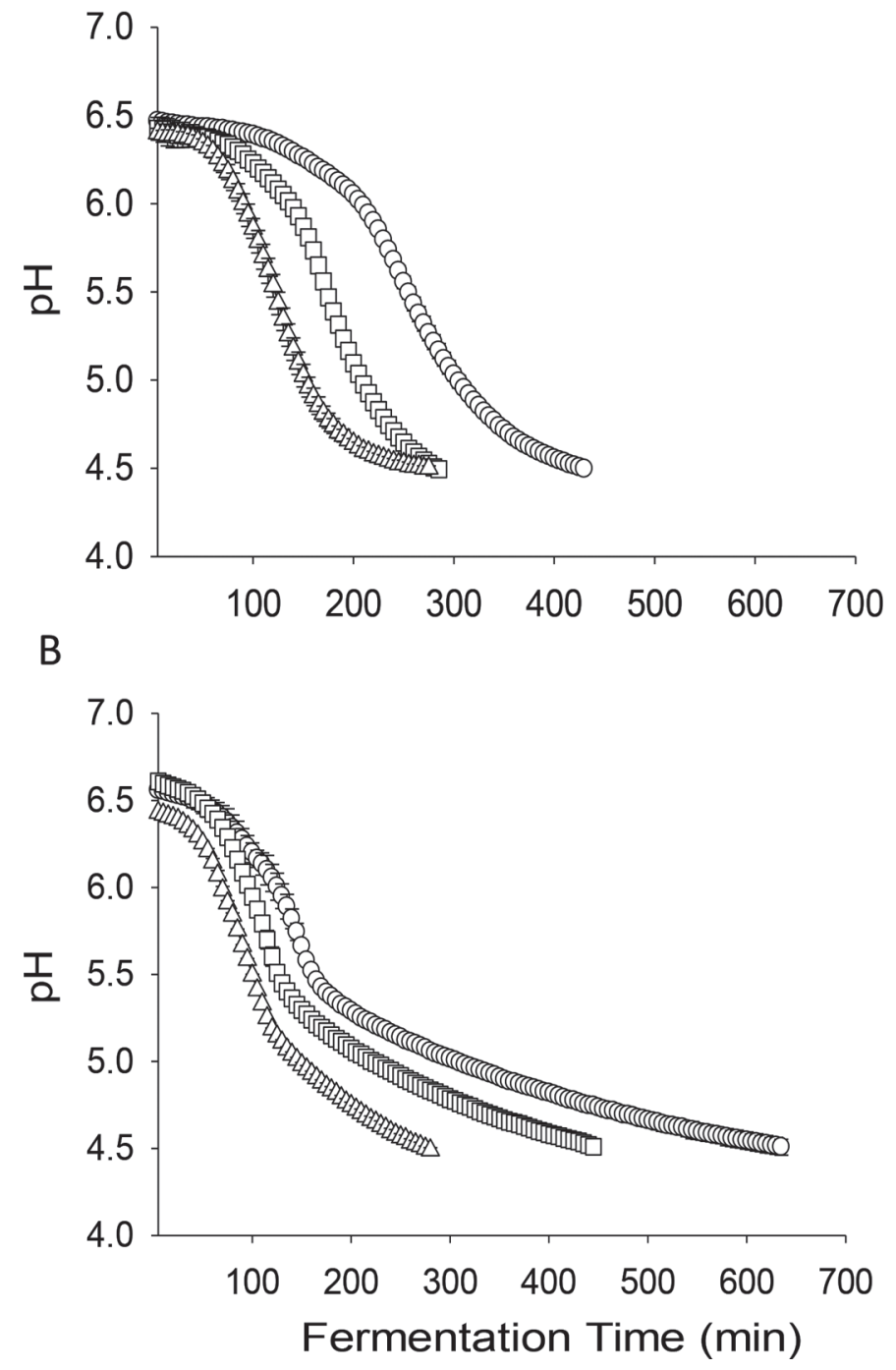

Figure 1. Change in $\mathrm{pH}$ values of milk during fermentation of milk by Streptococcus thermophilus strains St-143 (A) and DGCC7785 (B) at $33^{\circ} \mathrm{C}(\bigcirc), 39^{\circ} \mathrm{C}(\square)$, and $45^{\circ} \mathrm{C}(\triangle)$.

time. The molar mass of ropy EPS obtained at different $\mathrm{pH}$ values of milk during fermentation, at the 3 different fermentation temperatures, are shown in

Table 1. Yields of ropy exopolysaccharides (mg/L) produced by Streptococcus thermophilus strains St-143 and DGCC7785 during fermentation of milk at different temperatures ${ }^{1}$

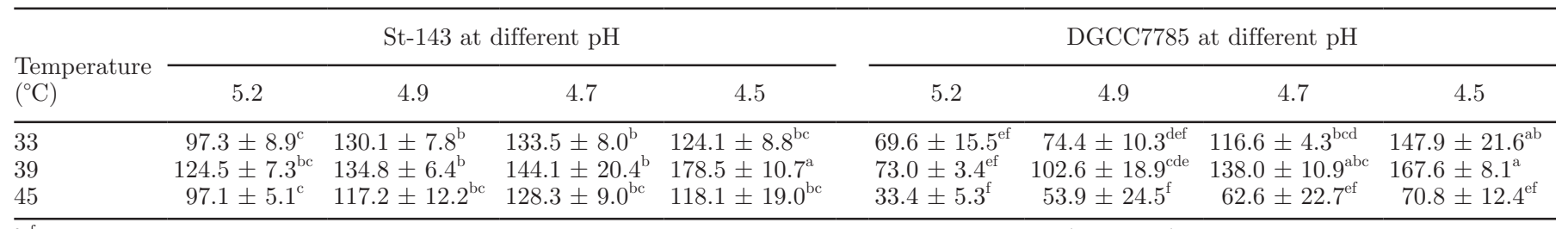

${ }^{\mathrm{a}-\mathrm{f}}$ Different superscripts within columns of ropy exopolysaccharides indicate significant difference $(P<0.05)$.

${ }^{1}$ Values are means $\pm \mathrm{SD}$ for $\mathrm{n}=4$. 
Figure 2. The molar mass of ropy EPS produced by strain St-143 at the 3 fermentation temperatures was mostly $\sim 2.8 \times 10^{6} \mathrm{~g} / \mathrm{mol}$ (Figure $2 \mathrm{a}$ ). The molar mass of EPS isolated from milk fermented by DGCC7785 at 33 or $39^{\circ} \mathrm{C}$ ranged between 2.0 and $2.3 \times 10^{6} \mathrm{~g} / \mathrm{mol}$ during fermentation (Figure $2 \mathrm{~b}$ ). However, we found high variability in the molar mass of EPS isolated from milk, especially at higher $\mathrm{pH}$ values and fermentation at $45^{\circ} \mathrm{C}$; we also noticed some slightly turbidity in these isolated fractions. All EPS samples had similar values for $\mathrm{R}_{g}$ (Figure 3 ), with no effect of fermentation tem-

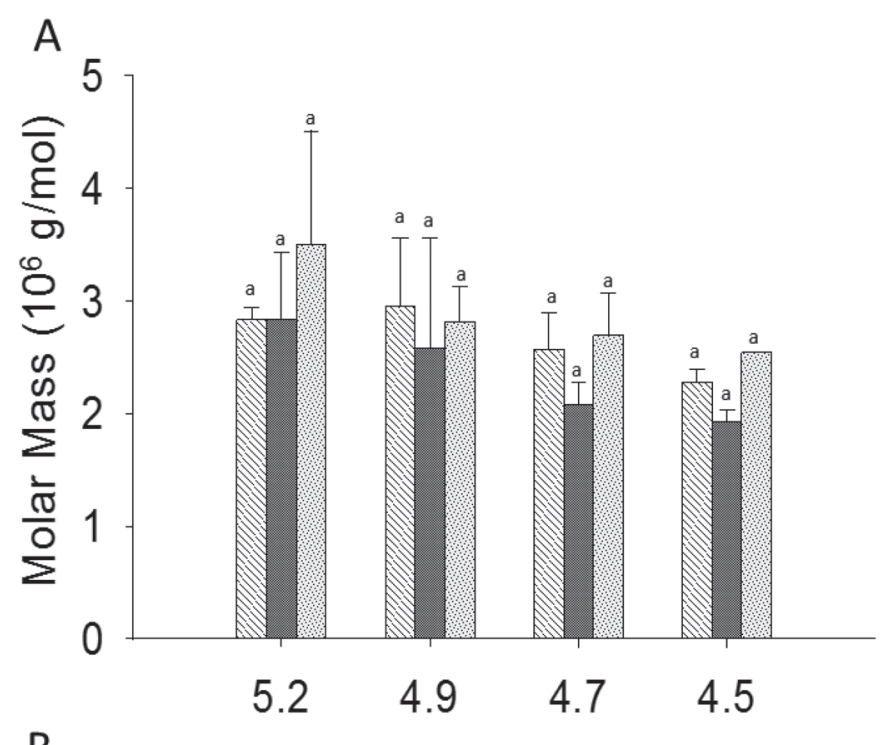

B

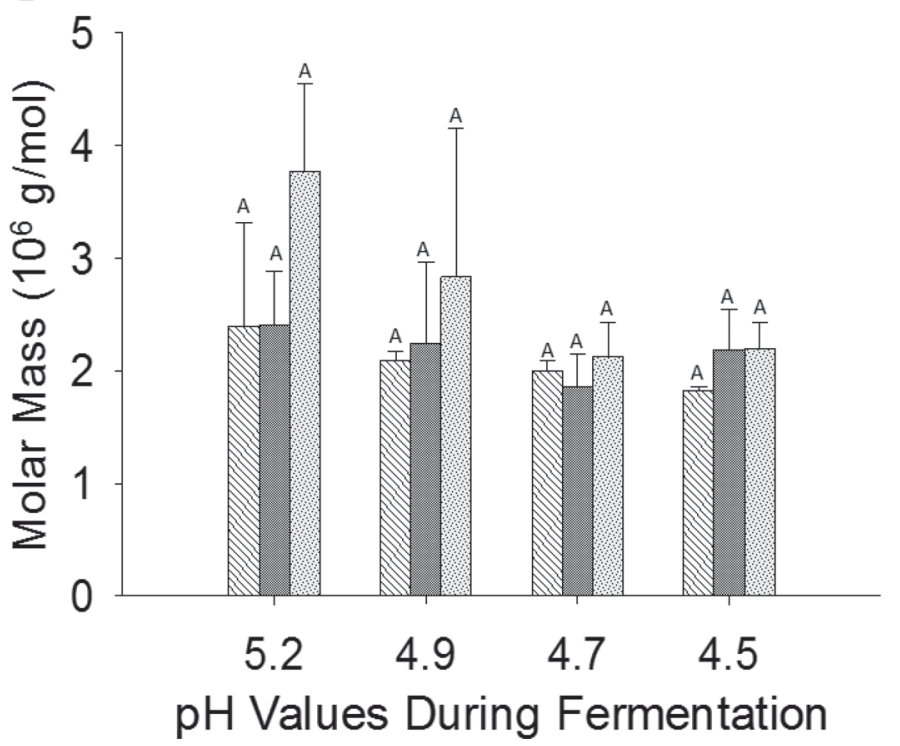

Figure 2. Molar mass of ropy exopolysaccharides isolated from milk fermented by Streptococcus thermophilus strains St-143 (A) and DGCC7785 (B) during fermentation at different temperatures. Bars with diagonal stripes $=33^{\circ} \mathrm{C}$; dark gray bars $=39^{\circ} \mathrm{C}$; hatched bars $=45^{\circ} \mathrm{C}$. Letters $(\mathrm{A}$, or a) represent no significant differences between treatments within each figure. Error bars indicate SD. perature or $\mathrm{pH}$ values. The values of $\mathrm{R}_{q}$ of the EPS produced by both strains were $\sim 60 \mathrm{~nm}$ (Figure 3 ). The EPS isolated from both strains were highly monodisperse as indicated by the PD values being close to 1.0 (results not shown).

\section{Rheological Properties of Milk Gels}

The $\mathrm{G}^{\prime}$ values of gels at various $\mathrm{pH}$ values during the fermentation of milk by strain St-143 are shown in Figure $4 \mathrm{a}$. The $\mathrm{G}^{\prime}$ values of the gel fermented by St-143 did not show any consistent increase during fermentation. We also observed no consistent trend for the $\mathrm{G}^{\prime}$ values for the different fermentation temperatures. Overall,
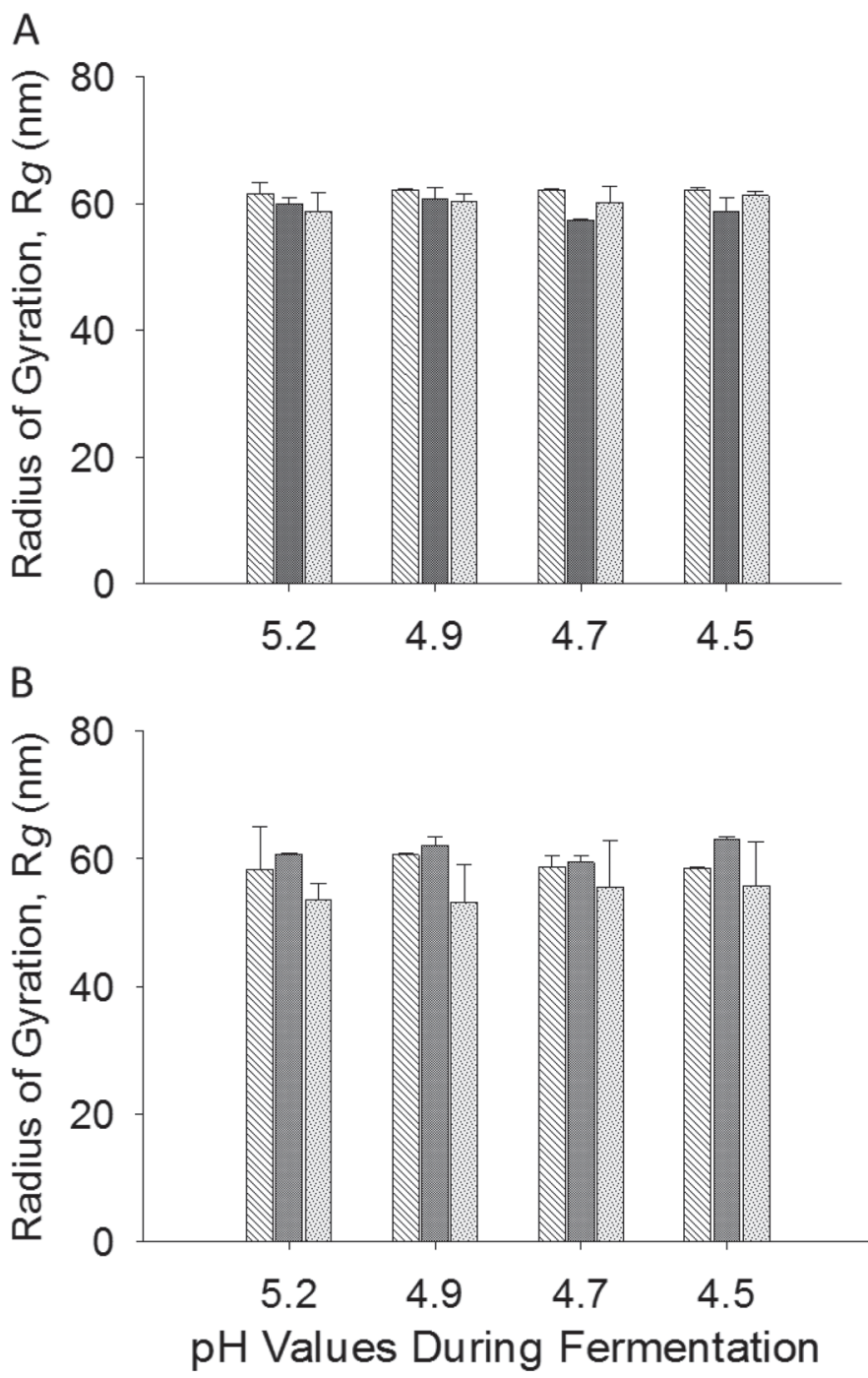

Figure 3. Radius of gyration $(\mathrm{R} g)$ of ropy exopolysaccharides isolated from milk fermented by Streptococcus thermophilus strains St143 (A) and DGCC7785 (B) during fermentation at different temperatures. Bars with diagonal stripes $=33^{\circ} \mathrm{C}$; dark gray bars $=39^{\circ} \mathrm{C}$; hatched bars $=45^{\circ} \mathrm{C}$. Error bars indicate SD. 
A

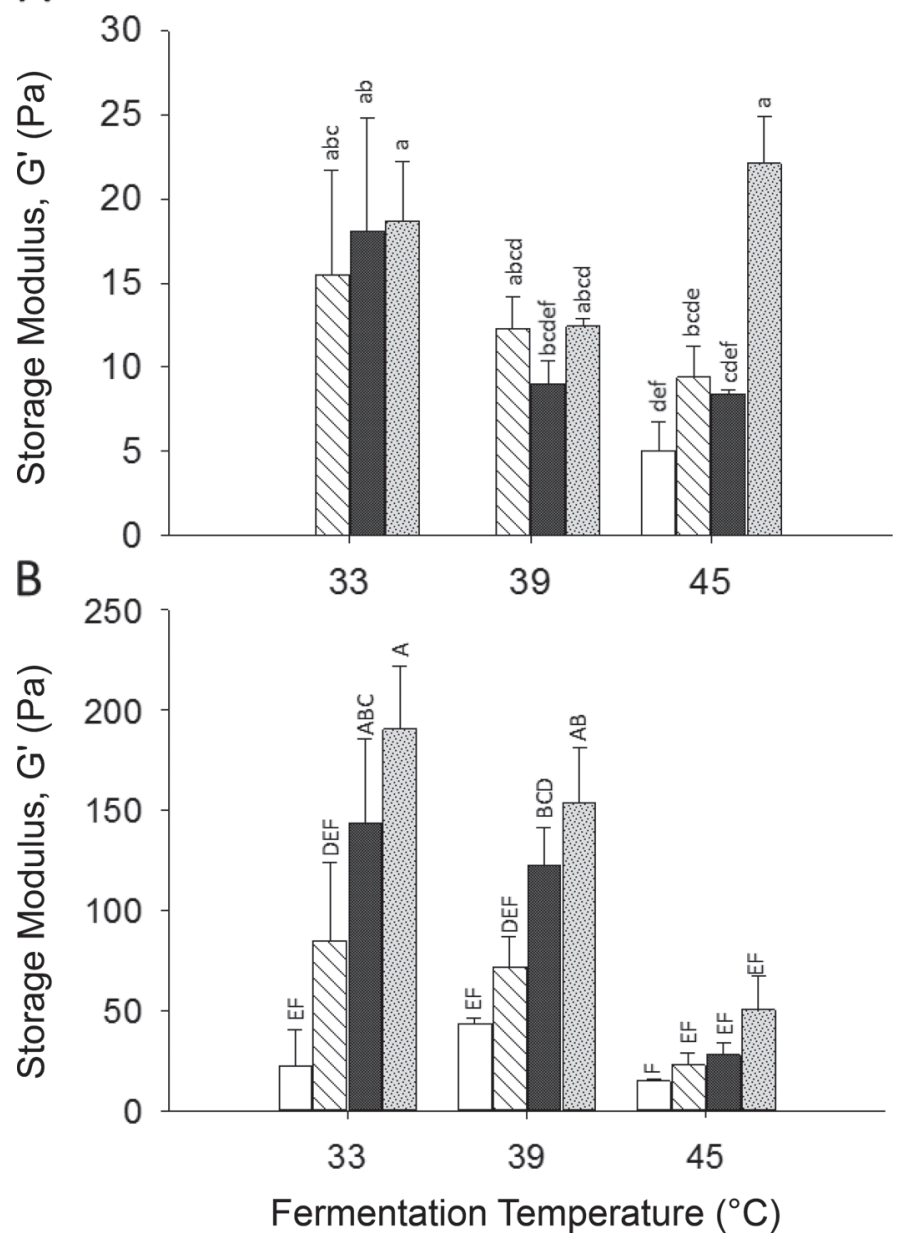

Figure 4. Values of storage moduli $\left(\mathrm{G}^{\prime}\right)$ of the acid milk gels formed by Streptococcus thermophilus strains St-143 (A) and DGCC7785 (B) during fermentation at different temperatures. White colored bars $=$ $\mathrm{pH} 5.2$; bars with diagonal stripes $=\mathrm{pH} 4.9$; dark colored bars $=\mathrm{pH}$ 4.7; hatched bars $=\mathrm{pH}$ 4.5. Different letters $(\mathrm{A}-\mathrm{F}$, or $\mathrm{a}-\mathrm{f})$ represent significant differences between treatments within each figure. Error bars indicate SD.

the $\mathrm{G}^{\prime}$ values of the gels formed by strain St-143 were very low $(<30 \mathrm{~Pa})$. In the gels made by fermentation with strain St-143, we noted a decrease in the $\mathrm{G}^{\prime}$ profile at $\mathrm{pH} \sim 4.9$ (result not shown), which contributed to the low $\mathrm{G}^{\prime}$ values at $\mathrm{pH}$ 4.5. When milk was fermented by strain DGCC7785, the $\mathrm{G}^{\prime}$ values gradually increased during fermentation period at all fermentation temperatures (Figure 4b). For strain DGCC7785, lower fermentation temperature resulted in significantly higher values of $\mathrm{G}^{\prime}$ during fermentation of milk.

Effect of fermentation temperatures on various rheological and gelation properties were also compared between the St-143 and DGCC7785 strains. Two-way ANOVA of the rheological data showed that these strains produced significantly different rheological properties of milk gels (Table 2). Gelation pH of milk ranged from $\mathrm{pH} 5.1$ to 5.4 depending on the strain and fermentation temperatures (Table 2). Milks fermented by strain DGCC7785 generally gelled at higher $\mathrm{pH}(\mathrm{pH}$ 5.3-5.4) than the milks fermented by strain St-143. For strain St-143, higher fermentation temperature (39 or $45^{\circ} \mathrm{C}$ ) also resulted in higher gelation $\mathrm{pH}$ values for gels. Gels exhibited a maximum in the LT ( $\left.\mathbf{L} \mathbf{T}_{\text {Max }}\right)$ shortly after gelation (Lucey et al., 1998). The $\mathrm{LT}_{\mathrm{Max}}$ values of gels fermented by strain St-143 at the different temperatures ranged from 0.452 to 0.562 , which were mostly higher than the $\mathrm{LT}_{\mathrm{Max}}$ values (0.433 to 0.521 ) of the gels formed by strain DGCC7785. Fermentation temperature also had significant effect on $\mathrm{LT}_{\text {Max }}$ values of the milk gels, with higher temperature resulted in higher $\mathrm{LT}_{\text {Max }}$ values (Table 2). When milk was fermented by strain DGCC7785 the $\mathrm{LT}_{\text {Max }}$ of gels occurred at $\mathrm{pH} 4.87$ to 5.09 , whereas $\mathrm{LT}_{\mathrm{Max}}$ occurred at $\mathrm{pH}$ values 4.73 to 4.87 when milk was fermented by strain St-143. The $\mathrm{G}^{\prime}$ values at $\mathrm{pH} 4.6$ were affected by fermentation temperatures, mainly due to the large effect of temperature on the $\mathrm{G}^{\prime}$ values of the gels formed by strain DGCC7785 (Table 2).

\section{Proteinaceous Contaminant of the Ropy EPS}

The SEC-MALLS chromatograms of ropy EPS samples isolated from milk fermented by both strains showed 2 distinct RI peaks, which eluted at 26-32 min

Table 2. Rheological properties of acid milk gel formed by Streptococcus thermophilus strains St-143 and DGCC7785 at different fermentation temperatures $^{1}$

\begin{tabular}{|c|c|c|c|c|c|c|c|c|}
\hline \multirow{2}{*}{$\begin{array}{l}\text { Temperature } \\
\left({ }^{\circ} \mathrm{C}\right)\end{array}$} & \multicolumn{2}{|c|}{$\mathrm{pH}_{\mathrm{Gel}}$} & \multicolumn{2}{|c|}{$\mathrm{LT}_{\text {Max }}$} & \multicolumn{2}{|c|}{$\mathrm{pH}$ at $\mathrm{LT}_{\mathrm{Max}}$} & \multicolumn{2}{|c|}{$\begin{array}{c}\mathrm{G}^{\prime} \text { values }(\mathrm{Pa}) \text { at } \\
\mathrm{pH} 4.6\end{array}$} \\
\hline & St-143 & DGCC7785 & St-143 & DGCC7785 & St-143 & DGCC7785 & St-143 & DGCC7785 \\
\hline 39 & $5.2 \pm 0.0^{\mathrm{cd}}$ & $5.4 \pm 0.0^{\mathrm{a}}$ & $0.481 \pm 0.01^{\mathrm{bc}}$ & $0.474 \pm 0.01^{\mathrm{cd}}$ & $4.73 \pm 0.01^{\mathrm{c}}$ & $5.09 \pm 0.04^{\mathrm{a}}$ & $11 \pm 0^{\mathrm{b}}$ & $142 \pm 19^{\mathrm{a}}$ \\
\hline 45 & $5.3 \pm 0.0^{\mathrm{bc}}$ & $5.3 \pm 0.0^{\mathrm{b}}$ & $0.562 \pm 0.01^{\mathrm{a}}$ & $0.521 \pm 0.01^{\mathrm{ab}}$ & $4.76 \pm 0.04^{\mathrm{bc}}$ & $4.87 \pm 0.01^{\mathrm{b}}$ & $12 \pm 1^{\mathrm{b}}$ & $40 \pm 7^{\mathrm{b}}$ \\
\hline
\end{tabular}

\footnotetext{
${ }^{\mathrm{a}-\mathrm{d}}$ Different superscripts for each rheological property indicate significant difference $(P<0.05)$.

${ }^{1}$ Values are means $\pm \mathrm{SD}$ for $\mathrm{n}=3 \cdot \mathrm{pH}_{\mathrm{Gel}}=\mathrm{pH}$ of gelation; $\mathrm{LT}_{\mathrm{Max}}=$ maximum loss tangent; $\mathrm{pH}$ at $\mathrm{LT}_{\mathrm{Max}}=\mathrm{pH}$ value during fermentation where $\mathrm{LT}_{\text {Max }}$ occurs; $\mathrm{G}^{\prime}=$ storage modulus.
} 
(peak 1) and 35-43 min (peak 2; Figure 5a); both peaks had high RI and MALLS signals, whereas only the second peak had a high UV signal (Figure 5a). The first RI peak had molar mass $\sim 2.0 \times 10^{6} \mathrm{~g} / \mathrm{mol}$, whereas the second RI peak had molar mass $\sim 5.0 \times 10^{5} \mathrm{~g} / \mathrm{mol}$. Hydrolysis of the EPS extract by trypsin and chymotrypsin eliminated all the detector signals at retention time of 35 to $43 \mathrm{~min}$ for the second peak (Figure 5b), confirming that these signals were due to the presence of a high-molecular-weight proteinaceous substance. As the molar mass value of $\sim 5.0 \times 10^{5} \mathrm{~g} / \mathrm{mol}$ was unusual for a protein, it was not clear what type of protein was the contaminant in the isolated EPS fraction. Liquid chromatography-MS/MS analysis of the tryptic digests of the material collected at retention time of 35 to 42 min showed several peptides that eluted at 85 to $95 \mathrm{~min}$ in these LC-MS/MS chromatograms (Figure 6). Comparison of these peptides against NCBInr Bos taurus and Uniprot Streptococcus thermophilus AA sequence databases showed that the most abundant protein present in the EPS extract isolated from milk fermented by both strains was a milk-derived phosphoglycoprotein PP3 (Accession: NP_777253.1). Overall sequence homology of the protein with PP3 was $76 \%$.

\section{DISCUSSION}

We evaluated the effects of fermentation temperature on the yields and properties of ropy EPS produced by S. thermophilus strains St-143 and DGCC7785 during fermentation of milk. These strains produced milk gels with very different rheological properties, so the goal of the study was to better understand how EPS affected rheological behavior. The effect of different fermentation temperatures on the rheological properties of milk gels formed by these strains were also studied, as both EPS concentrations and rheological properties would likely be affected by temperature.

Streptococcus thermophilus strains normally grow at mesophilic temperatures between 30 to $45^{\circ} \mathrm{C}$ (Faber et al., 1998; Vaningelgem et al., 2004b; Mozzi et al., 2006); fastest growth was observed at 39 to $45^{\circ} \mathrm{C}$ (Figure 1) in agreement with the previous reports. Exopolysaccharide-producing strains of $S$. thermophilus (strains Sts, Rts, and S3) grew at $32^{\circ} \mathrm{C}$ and also were found to produce EPS at this temperature (Faber et al., 1998, 2001). Many EPS-producing strains of S. thermophilus have been grown at 42 to $43^{\circ} \mathrm{C}$ and have been reported to produce significant levels of EPS $(8-290 \mathrm{mg} / \mathrm{L})$ at these temperatures (Doco et al., 1990; Vaningelgem et al., 2004b). At a controlled $\mathrm{pH}$ value of 5.8, EPSproducing S. thermophilus strain ST 111 showed good growth within the range 32 to $46^{\circ} \mathrm{C}$, with a maximal growth rate around $40^{\circ} \mathrm{C}$ (Vaningelgem et al., 2004a).
Even though the time required to ferment milk to $\mathrm{pH}$ 4.6 by both strains was matched at $40^{\circ} \mathrm{C}$ by supplementing the milk samples with peptone, differences in acidification rates by strains, especially at $33^{\circ} \mathrm{C}$, was observed (Figure 1). Such variations were likely due to differences in the proteolytic abilities and AA metabolism of $S$. thermophilus strains under different environmental conditions (Letort and Juillard, 2001).

Only a few previous studies have reported on the use of UF for the isolation and quantification of EPS from broth cultures; we used a UF method to quantify
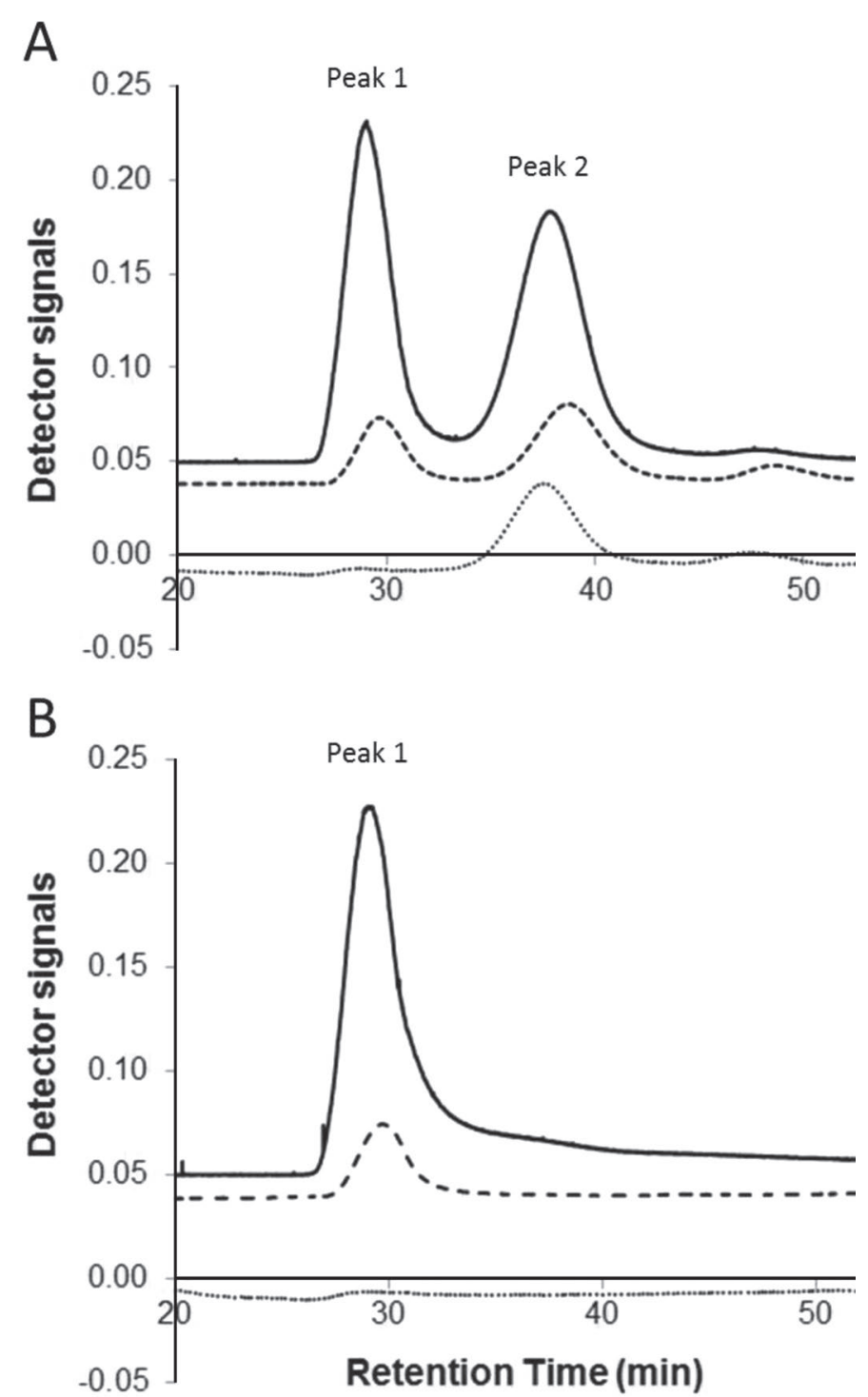

Figure 5. Size exclusion chromatography coupled with multiangle laser light-scattering detector signals (MALLS) before (A) and after (B) hydrolysis (by trypsin and chymotrypsin) of ropy exopolysaccharide extract isolated from milk fermented $(\mathrm{pH} \sim 4.7)$ by Streptococcus thermophilus DGCC7785 at $39^{\circ} \mathrm{C}$. Solid lines = MALLS signals; dashed lines $=$ refractive index signals; dotted lines $=\mathrm{UV}$ signals . 
the ropy EPS in fermented milk (Table 1). This approach provided isolated EPS that was highly soluble and avoided some of the difficulties with the analysis of the structural properties of EPS reported in a recent study when EPS was isolated with chemical precipitation (Pachekrepapol et al., 2017). Tuinier et al. (1999) isolated the EPS produced by Lactococcus lactis ssp. cremoris that was grown in whey permeate. When this retentate was diafiltered and freeze-dried, the resulting crude EPS powder contained $63 \%$ carbohydrate, $18 \%$ protein, and $8 \%$ minerals (Tuinier et al., 1999). Bergmaier et al. (2001) used UF to isolate the EPS produced by Lactobacillus rhamnosus, where they estimated that the efficiency of the isolation method was 85 to $100 \%$ in terms of recovery of the original EPS present in the whey permeate. A recent study used a pilot-scale tangential-flow UF membrane to isolate microalgal EPS from cell free culture (Li et al., 2011).

The yield of ropy EPS during fermentation was affected by the fermentation temperature, especially for DGCC7785 (Table 1). At $45^{\circ} \mathrm{C}$, although the rate of acidification by both strains was the fastest (Figure 1), significantly lower amounts of ropy EPS were observed in gels made with DGCC7785 (Table 1). Ropy EPS production appeared to increase during fermentation at all temperature for both strains (Table 1). It has been reported that EPS production occurred when bacteria were actively growing (Cerning, 1995; De Vuyst et al., 1998), which was the case for all the $\mathrm{pH}$ points tested in the current study.

The yield of ropy EPS $(70-178 \mathrm{mg} / \mathrm{L})$ in our study was within the range of yields of EPS (8-290 mg/L) reported during fermentation of milk by $S$. thermophilus strains (Faber et al., 1998; De Vuyst et al., 2003; Vaningelgem et al., 2004b; Mende et al., 2012). The yields of EPS from S. thermophilus strains St-143 and DGCC7785 in fermented milk were reported to be 65 and $43 \mathrm{mg}$ of $\mathrm{GE} / \mathrm{kg}$, respectively (Pachekrepapol et al., 2017). In most previous studies, the EPS isolation methods were based on chemical precipitation of protein by acids, such as TCA and EPS precipitation by ethanol or acetone (Mende et al., 2012; Leroy and De Vuyst, 2016; Pachekrepapol et al., 2017). In the precipitation-based methods, milk protein and bacterial cells are removed at an early stage of the isolation method, where a significant amount of ropy EPS are also likely lost along with protein (Rimada and Abraham, 2003). The resulting supernatant mostly contains the ropy type of EPS, which is also not fully recovered by ethanol precipitation (Goh et al., 2005). We retained

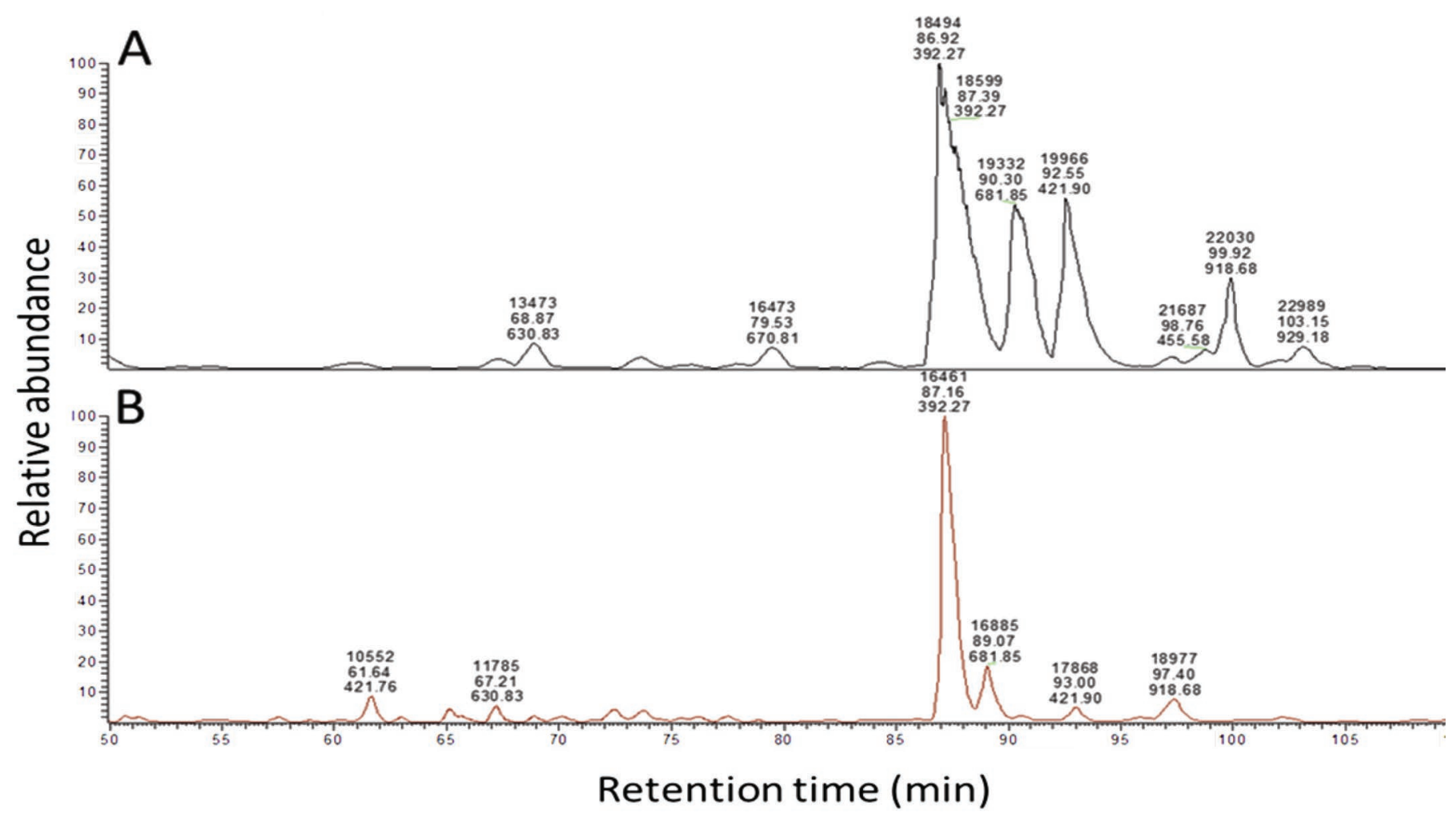

Figure 6. Liquid chromatography-MS/MS chromatogram of tryptic digest of the contaminating protein present in the ropy exopolysaccharides isolated from milk fermented by Streptococcus thermophilus strains DGCC7785 (A) and St-143 (B). Color version available online. 
the bacterial cells during protein removal and isolated the ropy EPS by UF. The current method seemed to have fewer opportunities for losses of ropy EPS; we believe most ropy EPS were retained by UF process. We also tested the viscosity of the UF permeate and it was low (close to water), suggesting it had a low EPS content. Based on the report by Bergmaier et al. (2001), 85 to $100 \%$ of the EPS present in a solution was recovered after UF using $35-\mathrm{kDa}$ membrane; the UF procedure in our study was expected to retain most of the EPS present in the whey as the EPS produced by most $S$. thermophilus strains had significantly higher molar mass $\left(>1.5 \times 10^{6} \mathrm{~g} / \mathrm{mol}\right)$ (Pachekrepapol et al., 2017; Khanal and Lucey, 2017) than the cut-off size of the UF membrane $\left(1 \times 10^{5} \mathrm{~g} / \mathrm{mol}\right)$.

The values of molar mass of EPS isolated during fermentation of milk by the $2 \mathrm{~S}$. thermophilus strains, St-143 and DGCC7785, varied from 2 to $4 \times 10^{6} \mathrm{~g} / \mathrm{mol}$, which were in general agreement with the past reports of molar mass of EPS $\left(1-5 \times 10^{6} \mathrm{~g} / \mathrm{mol}\right)$ produced by S. thermophilus strains (Doco et al., 1990; Lemoine et al., 1997; Faber et al., 1998). In an anaerobically fermented, semidefined medium grown at $40^{\circ} \mathrm{C}$ for $24 \mathrm{~h}$ at a constant $\mathrm{pH}$ 6.0, ST-143 produced EPS with molar mass ranging from $2.6 \times 10^{6}$ to $4.3 \times 10^{6} \mathrm{~g} / \mathrm{mol}$ (Mende et al., 2012, 2014). In that study, EPS was isolated by acetone precipitation and gel filtration chromatography was used for molar mass determination (Mende et al., 2012, 2014); SEC-MALLS directly measures molar mass instead of the use of calibration standards used for traditional gel filtration chromatography. The molar masses of EPS produced by the strains St-143 and DGCC7785 in milk fermented at $40^{\circ} \mathrm{C}$ to $\mathrm{pH} 4.6$ were $1.44 \times 10^{6}$ and $1.48 \times 10^{6} \mathrm{~g} / \mathrm{mol}$, respectively, as determined by SEC-MALLS (Pachekrepapol et al., 2017; Khanal and Lucey, 2017). These reports indicate that the small variation in the estimated molar masses of isolated EPS was probably due to the minor differences in fermentation media, conditions, or simply the molar mass determination techniques. Even though, the fermentation conditions and molar mass determination techniques (SEC-MALLS) were comparable to Pachekrepapol et al. (2017) and Khanal and Lucey (2017), the molar mass and $\mathrm{R}_{g}$ of EPS in our study were slightly higher, possibly due to the differences in the EPS isolation methods. With the ethanol precipitation method (Pachekrepapol et al., 2017; Khanal and Lucey, 2017), precipitated and resolubilized EPS molecules can lose some solubility, whereas the EPS isolated without precipitation or lyophilization (i.e., by purely physical separation methods, such as UF) likely retained their native properties resulting in slightly higher molar mass and size $\left(\mathrm{R}_{g}\right)$.
The major impurities in the isolated EPS fraction derived from fermented milk by our UF process were proteins, the major type was phosphoglycoprotein PP3 (Accession: NP_777253.1 or P80195) of milk origin. Other minor impurities were proteins derived from $S$. thermophilus, such as RNA polymerase, nuclease, signal recognition protein, phosphomevalonate kinase, and peptidoglycan binding protein. The proteins of bacterial origin had molar masses $>1.0 \times 10^{5} \mathrm{~g} / \mathrm{mol}$, which were retained by the $100-\mathrm{kDa}$ UF membrane used for the isolation of EPS. The most abundant contaminant, PP3, also called lactophorin, or glycosylation-dependent cell adhesion molecule-1 (GlyCAM-1), is one of the components of the proteose peptone fraction of milk. Bovine milk contains about $1 \mathrm{~g} / \mathrm{L}$ of proteose peptone fraction, including 25\% (200-300 mg/L) PP3 (Pedersen et al., 2012). The PP3 is composed of 135 AA residues and is highly soluble in water, as it is highly glycosylated. The PP3 has 3 O-glycosylation sites at $34(\mathrm{~T}), 78(\mathrm{~S})$, and $104(\mathrm{~T})$ residues, $1 \mathrm{~N}$-glycosylation site at $95(\mathrm{~N})$ residue, and 5 phosphoserine residues at 47, 52, 56, 58, and 64 positions in the sequence. The theoretical molar mass of PP3 is $1.72 \times 10^{4} \mathrm{~g} / \mathrm{mol}$; however, its total molar mass of the monomeric form was reported to be higher $\left(1.93-2.8 \times 10^{4} \mathrm{~g} / \mathrm{mol}\right)$ due to the presence of glycans attached at different glycosylation sites (Coddeville et al., 1998; Pedersen et al., 2012). The PP3 preferentially remains in multimeric structures of 4 to 10 times higher molar mass than its monomeric form. The molar mass of isolated multimeric PP3 fraction were reported to be $1.9-2.3 \times 10^{5} \mathrm{~g} / \mathrm{mol}$ (Sørensen et al., 1997; Pedersen et al., 2012), which were similar to the molar mass of the protein fraction co-isolated with EPS in our study (Figure 5).

The PP3 is highly stable at high temperatures $\left(90-100^{\circ} \mathrm{C}\right)$ as well as stable over a wide range of $\mathrm{pH}$, from $\mathrm{pH} 2$ to 9 . Thus, PP3 likely remained in the supernatant during our isolation process, along with the EPS, when protein was removed by heat or acid precipitation. With precipitation of EPS from supernatant by absolute ethanol, PP3 could also co-precipitate with EPS and end up in the final EPS isolate. Due to the presence of glycans, PP3 likely contributes to the amount of carbohydrate estimated during quantification of EPS, such as by the phenol sulfuric acid method. In some studies, including Vaningelgem et al. (2004b), EPS produced by LAB in milk medium was reported to have 2 fractions, one of higher molar mass $\left(>1 \times 10^{6} \mathrm{~g} / \mathrm{mol}\right)$, and the other fraction of lower molar masses. As the molar masses in most prior studies were analyzed by comparing the RI signals of the fractions isolated by gel permeation or size exclusion chromatography, it is possible that PP3 was mischaracterized as 
a lower molar mass EPS fraction. Such complications can be avoided during the isolation of EPS by including an additional protein hydrolysis step, such as in the current study (or by the 3 detector systems used by the SEC-MALLS technique).

The lower $\mathrm{G}^{\prime}$ value at $\mathrm{pH} 4.6$ with an increase in fermentation temperature for milk gels formed by $S$. thermophilus strain DGCC7785 (Figure 4b) was in general agreement with past studies (Lucey et al., 1997, 1998). Weaker acid casein gels were formed at higher temperatures when milk samples were gelled with either glucono- $\delta$-lactone or bacterial fermentation using yogurt starter cultures (Lucey et al., 1997, 1998; Lucey, 2002). Generally, due to reduced activity of bacteria, fermentation at lower temperature takes longer time to reach the required $\mathrm{pH}$ value. At $33^{\circ} \mathrm{C}$, the time required to reach $\mathrm{pH} 4.6$ was longer (Figure 1), which might have allowed more time to increase the stiffness of gel, such as by greater particle fusion. During the gel development process, at an early stage of gelation the casein particles may only be in partial surface contact, whereas they likely fuse more through rearrangement as the $\mathrm{pH}$ approaches the isoelectric point of casein (Peng et al., 2010). Significantly higher values for the $\mathrm{LT}_{\text {Max }}$ were observed with increasing the fermentation temperature (Table 2), suggesting that the susceptibility of the casein-casein bonds to break, or relax, increased when fermentation temperature was increased. When acid milk gels were formed at relatively higher temperature (such as $45^{\circ} \mathrm{C}$ ), the gels likely experienced more rearrangements due the increased hydrophobic interaction among the caseins causing greater particle shrinkage, and thereby decreasing the number of interactions among the particles and weakening the bonding in the network; this suggestion was in agreement with the increased $\mathrm{LT}_{\text {Max }}$ values (Lucey et al., 1998).

In contrast to the gels formed by strain DGCC7785, the $\mathrm{G}^{\prime}$ values at $\mathrm{pH} 4.6$ of gels formed by strain St143 were very low (11-20 Pa) at all fermentation temperatures (Table 2). Weak gels were also previously observed for milk fermented by strain St-143 (Khanal and Lucey, 2017); St-143 formed weak gels at $33^{\circ} \mathrm{C}$ even when the fermentation length was long (>400 min), and at low temperatures acid gels usually form stiff gels (Lucey et al., 1998). A likely explanation for the difference in the rheological properties of gels made by these 2 strains was the effect of the type of EPS (Khanal and Lucey, 2017). Generally speaking, at each fermentation temperature similar concentrations of ropy EPS were produced by both strains (Table 1). The type of EPS structures produced by strain St-143 and DGCC7785 were significantly different (Pachekrepapol et al., 2017). Strains DGCC7785 and St-143 produce EPS with 4 and 6 sugars-repeating units, respectively, and where the sugars in the linear chains of these EPS are connected by $\beta(1 \rightarrow 3)$ and $\beta(1 \rightarrow 4)$ linkages, respectively (Pachekrepapol et al., 2017). The role of specific EPS structures, such as the type of glycosidic linkages, on the properties of EPS in milk gels has not been well studied. Recently, Birch et al. (2017) indicated that charge density and polar interactions could play a role in how EPS interact with milk proteins. It has been suggested that carbohydrate polymers with $\beta(1 \rightarrow 4)$ linked structures were stiffer than with $\beta(1 \rightarrow 3)$-linked structures (Welman and Maddox, 2003). Uncharged EPS can induce depletion flocculation in casein systems (de Kruif and Tuinier, 2001). It is possible that the less-flexible $\beta(1 \rightarrow 4)$ EPS polymers produced by St-143 caused more incompatibility with the protein network, thereby contributing to further instability and weakening of the gel during the initial phase of gel formation. The higher values for the $\mathrm{LT}_{\mathrm{Max}}$ of the gels formed by St-143 were in agreement with our suggestion that an increase in the concentration of this type of EPS structure around the gelation point negatively affected the bond mobility (rearrangements) of the weak fragile gel network.

\section{CONCLUSIONS}

Using a UF method, we isolated highly soluble ropy EPS and analyzed its physical properties. The $2 S$. thermophilus strains acidified milk faster at $45^{\circ} \mathrm{C}$ but did not produce significantly higher amounts of EPS at this temperature. We found no significant change in the molar mass or radius of gyration of ropy EPS samples isolated at different $\mathrm{pH}$ values or when milks were fermented at different temperatures. Exopolysaccharide isolated from fermented milk by the UF method was contaminated with milk-derived phosphoglycoprotein PP3, which could be mischaracterized as a lower molar mass fraction EPS without the use of the techniques employed in this study. The effect of temperature on the rheological properties of fermented milk gel was also strain-dependent. The very weak gels formed by strain St-143, regardless of fermentation temperature, was possibly due to the effect of the specific structural properties of this type EPS (as the concentrations and molar masses of the EPS produced by both strains at the different temperatures were not significantly different).

\section{ACKNOWLEDGMENTS}

The article is based on work funded by National Institute of Food and Agriculture, USDA (Washington, DC), Hatch project (WISO1650). The authors acknowledge Yanjie Lu, researcher at the Center for Dairy Research, 
as well as Fan Wang, and Celine Lie, undergraduate researchers in Department of Food Science, University of Wisconsin-Madison, for their help during this research. All research carried out with strains from Chr. Hansen A/S (Milwaukee, WI) was covered by valid agreements. We also thank Danisco USA Inc. (Madison, WI) for their donation of cultures used in this study.

\section{REFERENCES}

Bergmaier, D., C. Lacroix, M. G. Macedo, and C. Champagne. 2001. New method for exopolysaccharide determination in culture broth using stirred UF cells. Appl. Microbiol. Biotechnol. 57:401-406.

Birch, J., H. K. Harð̄arson, S. Khan, M.-R. Van Calsteren, R. Ipsen, C. Garrigues, K. Almdal, M. A. Hachem, and B. Svensson. 2017. Effect of repeat unit structure and molecular mass of lactic acid bacteria hetero-exopolysaccharides on binding to milk proteins. Carbohydr. Polym. 177:406-414.

Cerning, J. 1990. Exocellular polysaccharides produced by lactic acid bacteria. FEMS Microbiol. Rev. 7:113-130.

Cerning. J. 1995. Production of exopolysaccharides by lactic acid bacteria and dairy propionibacteria. Lait 75:463-472.

Coddeville, B., J.-M. Girardet, Y. Plancke, S. Campagna, G. Linden, and G. Spik. 1998. Structure of the O-glycopeptides isolated from bovine milk component PP3. Glycoconj. J. 15:371-378.

de Kruif, C. G., and R. Tuinier. 2001. Polysaccharide protein interactions. Food Hydrocoll. 15:555-563.

De Vuyst, L., F. De Vin, F. Vaningelgem, and B. Degeest. 2001. Recent developments in the biosynthesis and applications of heteropolysaccharides from lactic acid bacteria. Int. Dairy J. 11:687-707.

De Vuyst, L., F. Vanderveken, S. Van de Ven, and B. Degeest. 1998. Production by and isolation of exopolysaccharides from Streptococcus thermophilus grown in a milk medium and evidence for their growth-associated biosynthesis. J. Appl. Microbiol. 84:1059-1068.

De Vuyst, L., M. Zamfir, F. Mozzi, T. Adriany, V. Marshall, B. Degeest, and F. Vaningelgem. 2003. Exopolysaccharide-producing Streptococcus thermophilus strains as functional starter cultures in the production of fermented milks. Int. Dairy J. 13:707-717.

Degeest, B., B. Janssens, and L. De Vuyst. 2001. Exopolysaccharide (EPS) biosynthesis by Lactobacillus sakei $0-1$ : Production kinetics, enzyme activities and EPS yields. J. Appl. Microbiol. 91:470-477.

Del Valle-Echevarria, A. R., A. Kielkowska, G. Bartoszewski, and M. J. Harvey. 2015. The mosaic mutants of cucumber: a method to produce known-downs of mitochondrial transcripts. G3 (Bethesda) 5:1211-1221.

di Cagno, M., T. Terndrup Nielsen, K. Lambertsen Larsen, J. Kuntsche, and A. Bauer-Brandl. 2014. $\beta$-cyclodextrin-dextran polymers for the solubilization of poorly soluble drugs. Int. J. Pharm. 468:258-263.

Doco, T., J.-M. Wieruszeski, B. Fournet, D. Carcano, P. Ramos, and A. Loones. 1990. Structure of an exocellular polysaccharide produced by Streptococcus thermophilus. Carbohydr. Res. 198:313321.

Dubois, M., K. A. Gilles, J. K. Hamilton, P. Rebers, and F. Smith. 1956. Colorimetric method for determination of sugars and related substances. Anal. Chem. 28:350-356.

Faber, E. J., M. J. van den Haak, J. P. Kamerling, and J. F. Vliegenthart. 2001. Structure of the exopolysaccharide produced by Streptococcus thermophilus S3. Carbohydr. Res. 331:173-182.

Faber, E. J., P. Zoon, J. P. Kamerling, and J. F. G. Vliegenthart. 1998. The exopolysaccharides produced by Streptococcus thermophilus Rs and Sts have the same repeating unit but differ in viscosity of their milk cultures. Carbohydr. Res. 310:269-276.

Gamar-Nourani, L., K. Blondeau, and J. M. Simonet. 1998. Influence of culture conditions on exopolysaccharide production by Lactobacillus rhamnosus strain C83. J. Appl. Microbiol. 85:664-672.

Gassem, M. A., K. A. Sims, and J. F. Frank. 1997. Extracellular polysaccharide production by Lactobacillus delbrueckii ssp. bulgaricus
RR in a continuous fermentor. Lebensm. Wiss. Technol. 30:273278.

Goh, K. K. T., D. R. Haisman, R. H. Archer, and H. Singh. 2005. Evaluation and modification of existing methods for the quantification of exopolysaccharides in milk-based media. Food Res. Int. $38: 605-613$.

Hassan, A. N. 2008. Possibilities and challenges of exopolysaccharideproducing lactic cultures in dairy foods. J. Dairy Sci. 91:1282-1298.

Kessner, D., M. Chambers, R. Burke, D. Agus, and P. Mallick. 2008 Proteowizard: Open source software for rapid proteomics tools development. Bioinformatics 24:2534-2536.

Khanal, S. N., and J. A. Lucey. 2017. Evaluation of the yield, molar mass of exopolysaccharides, and rheological properties of gels formed during fermentation of milk by Streptococcus thermophilus strains St-143 and ST-10255y. J. Dairy Sci. 100:6906-6917.

Lee, W.-J., and J. A. Lucey. 2003. Rheological properties, whey separation, and microstructure in set-style yogurt: Effects of heating temperature and incubation temperature. J. Texture Stud. 34:515536.

Lee, W. J., and J. A. Lucey. 2004. Structure and physical properties of yogurt gels: Effect of inoculation rate and incubation temperature. J. Dairy Sci. 87:3153-3164.

Lemoine, J., F. Chirat, J.-M. Wieruszeski, G. Strecker, N. Favre, and J.-R. Neeser. 1997. Structural characterization of the exocellular polysaccharides produced by Streptococcus thermophilus Sfi39 and Sfi12. Appl. Environ. Microbiol. 63:3512-3518.

Leroy, F., and L. De Vuyst. 2016. Advances in production and simplified methods for recovery and quantification of exopolysaccharides for applications in food and health. J. Dairy Sci. 99:3229-3238.

Letort, C., and V. Juillard. 2001. Development of a minimal chemically-defined medium for the exponential growth of Streptococcus thermophilus. J. Appl. Microbiol. 91:1023-1029.

Li, H., Z. Li, S. Xiong, H. Zhang, N. Li, S. Zhou, Y. Liu, and Z. Huang. 2011. Pilot-scale isolation of bioactive extracellular polymeric substances from cell-free media of mass microalgal cultures using tangential-flow UF. Process Biochem. 46:1104-1109.

Lucey, J. A. 2002. Formation and physical properties of milk protein gels. J. Dairy Sci. 85:281-294.

Lucey, J., M. Tamehana, H. Singh, and P. Munro. 1998. A comparison of the formation, rheological properties and microstructure of acid skim milk gels made with a bacterial culture or glucono- $\delta$-lactone. Food Res. Int. 31:147-155.

Lucey, J., T. Van Vliet, K. Grolle, T. Geurts, and P. Walstra. 1997. Properties of acid casein gels made by acidification with glucono- $\delta$ lactone. 1. Rheological properties. Int. Dairy J. 7:381-388.

Mende, S., T. Dong, A. Rathemacher, H. Rohm, and D. Jaros. 2014. Physicochemical characterisation of the exopolysaccharides of Streptococcus thermophilus St-143. Int. J. Food Sci. Technol. 49:1254-1263.

Mende, S., C. Mentner, S. Thomas, H. Rohm, and D. Jaros. 2012. Exopolysaccharide production by three different strains of Streptococcus thermophilus and its effect on physical properties of acidified milk. Eng. Life Sci. 12:466-474.

Mende, S., H. Rohm, and D. Jaros. 2016. Influence of exopolysaccharides on the structure, texture, stability and sensory properties of yoghurt and related products. Int. Dairy J. 52:57-71.

Mozzi, F., F. Vaningelgem, E. M. Hébert, R. Van der Meulen, M. R. F. Moreno, G. F. de Valdez, and L. De Vuyst. 2006. Diversity of heteropolysaccharide-producing lactic acid bacterium strains and their biopolymers. Appl. Environ. Microbiol. 72:4431-4435.

Pachekrepapol, U., J. A. Lucey, Y. Gong, R. Naran, and P. Azadi. 2017. Characterization of the chemical structures and physical properties of exopolysaccharides produced by various Streptococcus thermophilus strains. J. Dairy Sci. 100:3424-3435.

Pedersen, L. R. L., S. B. Nielsen, J. G. Hansted, T. E. Petersen, D E. Otzen, and E. S. Sørensen. 2012. PP3 forms stable tetrameric structures through hydrophobic interactions via the C-terminal amphipathic helix and undergoes reversible thermal dissociation and denaturation. FEBS J. 279:336-347.

Peng, Y., D. S. Horne, and J. A. Lucey. 2010. Physical properties of acid milk gels prepared at $37^{\circ} \mathrm{C}$ up to gelation but at different in- 
cubation temperatures for the remainder of fermentation. J. Dairy Sci. 93:1910-1917.

Rimada, P. S., and A. G. Abraham. 2003. Comparative study of different methodologies to determine the exopolysaccharide produced by kefir grains in milk and whey. Lait 83:79-87.

Sørensen, E. S., L. Rasmussen, L. Møller, and T. Petersen. 1997. The localization and multimeric nature of component PP3 in bovine milk: Purification and characterization of PP3 from caprine and ovine milks. J. Dairy Sci. 80:3176-3181.

Tallon, R., P. Bressollier, and M. C. Urdaci. 2003. Isolation and characterization of two exopolysaccharides produced by Lactobacillus plantarum EP56. Res. Microbiol. 154:705-712.

Tamime, A. Y., and R. K. Robinson. 1999. Yoghurt: Science and Technology. 2nd ed. CRC Press, Boca Raton, FL.

Torino, M. I., M. Taranto, F. Sesma, and G. De Valdez. 2001a. Heterofermentative pattern and exopolysaccharide production by Lactobacillus helveticus ATCC 15807 in response to environmental $\mathrm{pH}$ J. Appl. Microbiol. 91:846-852.

Torino, M. I., M. P. Taranto, and G. Font de Valdez. 2001b. Mixedacid fermentation and polysaccharide production by Lactobacillus helveticus in milk cultures. Biotechnol. Lett. 23:1799-1802.
Tuinier, R., P. Zoon, C. Olieman, M. A. C. Stuart, G. Fleer, and C. de Kruif. 1999. Isolation and physical characterization of an exocellular polysaccharide. Biopolymers 49:1-9.

Vaningelgem, F., M. Zamfir, T. Adriany, and L. De Vuyst. 2004a. Fermentation conditions affecting the bacterial growth and exopolysaccharide production by Streptococcus thermophilus ST 111 in milk-based medium. J. Appl. Microbiol. 97:1257-1273.

Vaningelgem, F., M. Zamfir, F. Mozzi, T. Adriany, M. Vancanneyt, J. Swings, and L. De Vuyst. 2004b. Biodiversity of exopolysaccharides produced by Streptococcus thermophilus strains is reflected in their production and their molecular and functional characteristics. Appl. Environ. Microbiol. 70:900-912.

Wang, T., and J. A. Lucey. 2003. Use of multi-angle laser light scattering and size-exclusion chromatography to characterize the molecular weight and types of aggregates present in commercial whey protein products. J. Dairy Sci. 86:3090-3101.

Welman, A. D., and I. S. Maddox. 2003. Exopolysaccharides from lactic acid bacteria: Perspectives and challenges. Trends Biotechnol. 21:269-274. 